\title{
PHENOTYPIC MODULATION OF HUMAN ARTICULAR CHONDROCYTES BY BISTRATENE A
}

\author{
B.J. Gargiulo ${ }^{1}$, P. Cragg ${ }^{1}$, J.B. Richardson ${ }^{2}$, B.A. Ashton ${ }^{1}$ and W.E.B. Johnson ${ }^{3 *}$ \\ ${ }^{1}$ L.M.A.R.C., ${ }^{2}$ Institute of Orthopaedics, ${ }^{3}$ Centre for Spinal Studies, Robert Jones and Agnes Hunt Orthopaedic \\ Hospital, Oswestry, Shropshire SY10 7AG, U.K.
}

\begin{abstract}
Chondrocytes undergo phenotypic alterations following extended periods in monolayer culture, i.e., they become bipolar and flattened, proliferate, and synthesise type I as opposed to type II collagen. This process has been termed chondrocyte dedifferentiation. Bistratene $\mathrm{A}$ is a macrolide polyether that specifically activates the delta isoform of protein kinase $\mathrm{C}(\mathrm{PKC} \delta)$ in some cell types. Here, we show that dedifferentiated human articular chondrocytes became rounded and underwent cell growth arrest after treatment with bistratene A. In addition, bistratene Atreated chondrocytes became more immunopositive for type II collagen, but less immunopositive for type I collagen. These phenotypic changes were associated with a prior and extensive disruption of actin microfilaments and translocation of PKC $\delta$ to the nuclear membrane. Concurrent treatments of chondrocytes with a specific inhibitor of $\mathrm{PKC} \delta$, rottlerin, partially blocked the morphological effects of bistratene A.
\end{abstract}

Key Words: Bistratene A, protein kinase C, articular chondrocyte, cell shape and differentiation.

*Address for correspondence:

W.E.B. Johnson

Centre for Spinal Studies, Robert Jones and Agnes Hunt Orthopaedic Hospital, Oswestry, Shropshire SY10 7AG, U.K.

FAX Number: +44-1691-404054

E-mail: w.e.b.johnson@keele.ac.uk

\section{Introduction}

In vivo, most human articular chondrocytes display a spherical or oval morphology, are normally non-proliferative and characteristically express type II collagen. Following isolation and culture as monolayers, however, these cells adopt a flattened and elongated "fibroblastlike" shape, they enter cell cycle, proliferate, and cease synthesising type II collagen in favour of type I (von der Mark et al., 1977; Benya et al., 1978). Such behaviour, termed dedifferentiation, has been of use to clinicians and tissue engineers in that it provides an increased cell population during autologous chondrocyte transplantation procedures that promote the repair or replacement of damaged cartilage (Richardson et al., 1999). However, in order to produce a hyaline-like cartilage, that consists of appropriate matrix molecules including type II but not type I collagen, the re-expression of a mature chondrocytic phenotype is required. Previous studies have shown that returning flattened chondrocytes to a spherical (rounded) cell shape induces their renewed maturation or redifferentiation, i.e., the cells become less proliferative and reexpress type II collagen (Benya and Shaffer, 1982). Mature chondrocyte growth has thus been encouraged by utilising alternative in vitro culture conditions, such as embedding cells within gels or through culture with fibrous materials too fine to permit the cells to flatten and spread (Benya and Shaffer, 1982; Freed et al., 1994).

Despite its importance to cartilaginous tissue engineering, the mechanisms that regulate chondrocyte shape and differentiation in vitro remain relatively poorly understood. Several workers have suggested that the organisation of actin microfilaments within cultured chondrocytes is intrinsically linked to their shape and/or collagen synthesis (Benya et al., 1988; Brown and Benya, 1988). In general, the formation of actin stress fibres in cells of the chondrogenic lineage appears to inhibit the expression of differentiated chondrocyte markers (Benya and Shaffer, 1982; Zanetti and Solursh, 1984; Mallein-Gerin et al., 1991). However, the intracellular regulatory molecules that determine the structure of the actin cytoskeleton and chondrocyte shape are largely unknown. A number of studies have suggested that the delta isoform of protein kinase $\mathrm{C}(\mathrm{PKC})$ represents a likely target in the regulation of cell morphology. For example, over-expression of PKC $\delta$ in NIH $3 \mathrm{~T} 3$ fibroblasts results in their rounding, growth inhibition and reduced adherance (Mischak et al., 1993). In addition, both the focal adhesion kinase pp125FAK and PKC $\delta$ are recruited, along with the 
cytoskeletal proteins talin, paxillin, and vinculin, to newly formed focal adhesions in fibroblasts in response to serum (Barry and Critchley, 1994). Furthermore, IL-3 withdrawal from Baf3 (B cell lymphoma) cells disrupts membrane ruffling and induces cell rounding, but overexpression of a dominant negative PKC $\delta$ (but not of other PKC isoforms) inhibits these effects, i.e., activation of $\mathrm{PKC} \delta$ is required for the disruption of membrane ruffles (Romanova et al., 1999).

Bistratene A (bis A) is a macrolide polyether toxin that specifically activates PKC $\delta$ in a variety of cell types (Watters et al., 1996; Griffiths et al., 1996; Watters et al., 1998). In fibroblasts, bis A treatment induces reorganisation of the actin cytoskeleton, a rounded morphology and detachment from tissue culture substrates (Watters et al., 1996), whilst in cultured melanoma cells treatment with bis A similarly alters cell morphology and induces onset of melanocyte differentiation (Watters et al., 1998). Here, we describe the effects of bis A on the shape, growth and phenotype of cultured human articular chondrocytes.

\section{Materials and Methods}

Human articular chondrocytes were isolated from donor biopsies of macroscopically normal cartilage. These biopsies were obtained from patients ( 2 male, 5 female, ages 25-73 years) with osteochondral defects or ostearthritic lesions of other regions of the knee or hip. Tissue samples were finely dissected and chondrocytes obtained following enzymic digestion in type XI collagenase (C 9407, Sigma, Poole, UK) at a concentration of $0.8 \mathrm{mg} / \mathrm{ml}$ in DMEM/F12 culture medium (Life Technologies Ltd, Paisley, Scotland) and DNAse (D4263 Sigma, 333U/ml in culture medium) for a period of 18 hours at $37^{\circ} \mathrm{C}$. Digested samples were filtered through a $70 \mu \mathrm{m}$ mesh and obtained cells washed twice by centrifuging and resuspending in DMEM/F12, before seeding into flasks in DMEM/F12 medium (Life Technologies) supplemented with $20 \%$ foetal bovine serum (FBS, Life Technologies), L-ascorbic acid $(50 \mathrm{mg} / \mathrm{ml}$, AnalaR, Merck Ltd, Lutterworth, UK) and antibiotics $(50 \mathrm{mg} / \mathrm{ml}$ Gentamicin; $2.5 \mathrm{mg} / \mathrm{ml} \mathrm{Amphotericin).} \mathrm{After} 5$ days of culture, any non-adherent cells were discarded, whilst adherent cells were cultured as monolayers in medium containing $10 \%$ FBS for a further 2-4 passages, at which time all cells exhibited a "fibroblast-like" morphology. Monolayered cells were passaged at $70 \%$ confluence using trypsin/EDTA solution (45300-019; Gibco, Life Technologies).

For each experiment, $5 \times 10^{3}$ cells $/ \mathrm{cm}^{2}$ were seeded onto tissue culture slides (Nunc LabTek, Life Technologies) or in $\mathrm{T} 25 \mathrm{~cm}^{2}$ tissue culture flasks (Life Technologies), permitted to adhere and spread for 24 hours, and then treated with medium containing either $100 \mathrm{ng} / \mathrm{ml}$ bis A or, as control cultures, with carrier alone (DMSO dissolved 1/10 000 in DMEM/F12). Parallel flask cultures were treated with medium supplemented with the $\mathrm{PKC} \delta$-specific inhibitor, $5 \mathrm{mM}$ rottlerin (Gschwendt et al., 1994), alone and in addition to $100 \mathrm{ng} / \mathrm{ml}$ bis A. Medium was completely replaced with fresh bis A-treated or control medium, as appropriate, after 3 days. Viable cell number was determined using trypan blue exclusion of trypsinised cultures and culture viability further assessed using incorporation of propidium iodide (PI, Sigma) and fluorescein diacetate (F-7378; Sigma) into unfixed cells, adapting methods previously described (Jones and Senft, 1985). Cells harvested by trypsinisation were used for cytocentrifuge preparations (cytospins) which were later analysed in some immunolocalisation studies (see below).

The appearance of cells in culture was recorded using phase contrast microscopy with an image capture system or by Jenner and Giemsa staining of harvested culture slides. Immunolocalisation of parallel culture slides was performed for PKC $\delta$ (1/500 polyclonal anti-human PKC $\delta$, Santa Cruz Biotechnology Inc., Santa Cruz, California, USA) using a secondary sheep anti-rabbit antibody conjugated with fluorescein (Vector Laboratories, Peterborough, UK). Filamentous actin was visualised following labelling of culture slides with fluorescein-conjugated phalloidin (Sigma). Cytospins of cells harvested from culture flasks, and day 5 culture slides, were used for immunolocalisation of the proliferation-associated Ki-67 antigen (1/50 Clone MM1, Novacastra, Newcastle-uponTyne, UK), type I collagen (1/100 Clone I-8H5, ICN, Basingstoke, UK) and type II collagen (1/10 monoclonal CIICI, Developmental Studies Hybridoma Bank, USA). Immunopositivity for these proteins was revealed using commercial secondary labelling systems (Vector Laboratories) combined with 3.3' diaminobenzidine (DAB, for the $\mathrm{Ki}-67$ antigen, and types I and II collagen in day 5 cultures slides) or fluorescein (day 5 cytospins for types I and II collagen). All immunolocalisations using fluorescein for visualisation of immunopositivity were counterstained with a commercial mountant containing PI (Vector Laboratories), whilst those using DAB were counterstained with Meyer's haematoxylin. Control immunolabelling of parallel cultures and cytospins using isotype-matched antisera was negative. A minimum of 200 cells/sample were scored, using conventional light and fluorescent microscopy, to determine the proportions of cells in cytospins expressing the Ki-67 antigen, type I collagen or type II collagen. The relative pixel intensity of cells immunolabelled for types I and II collagen (where immunopositivity was revealed by fluorescein) was determined using a confocal microscope and associated software (LSM510, Zeiss, Welwyn Garden City, UK). All data given represent means \pm standard errors of at least 3 independent experiments, i.e., using chondrocytes derived from at least 3 donors.

\section{Results}

Control articular chondrocytes exhibited a "fibroblastlike" morphology in monolayer, appearing flattened and bipolar throughout a 5-day time course. By contrast, following the addition of bis A-supplemented medium, flattened chondrocytes began retracting their extended cell processes and adopted a rounded morphology. Cell process retraction was observed 20-30 minutes after the addition of bis $\mathrm{A}$ to the culture medium and by 60 minutes, all bis A-treated chondrocytes had become rounded but 

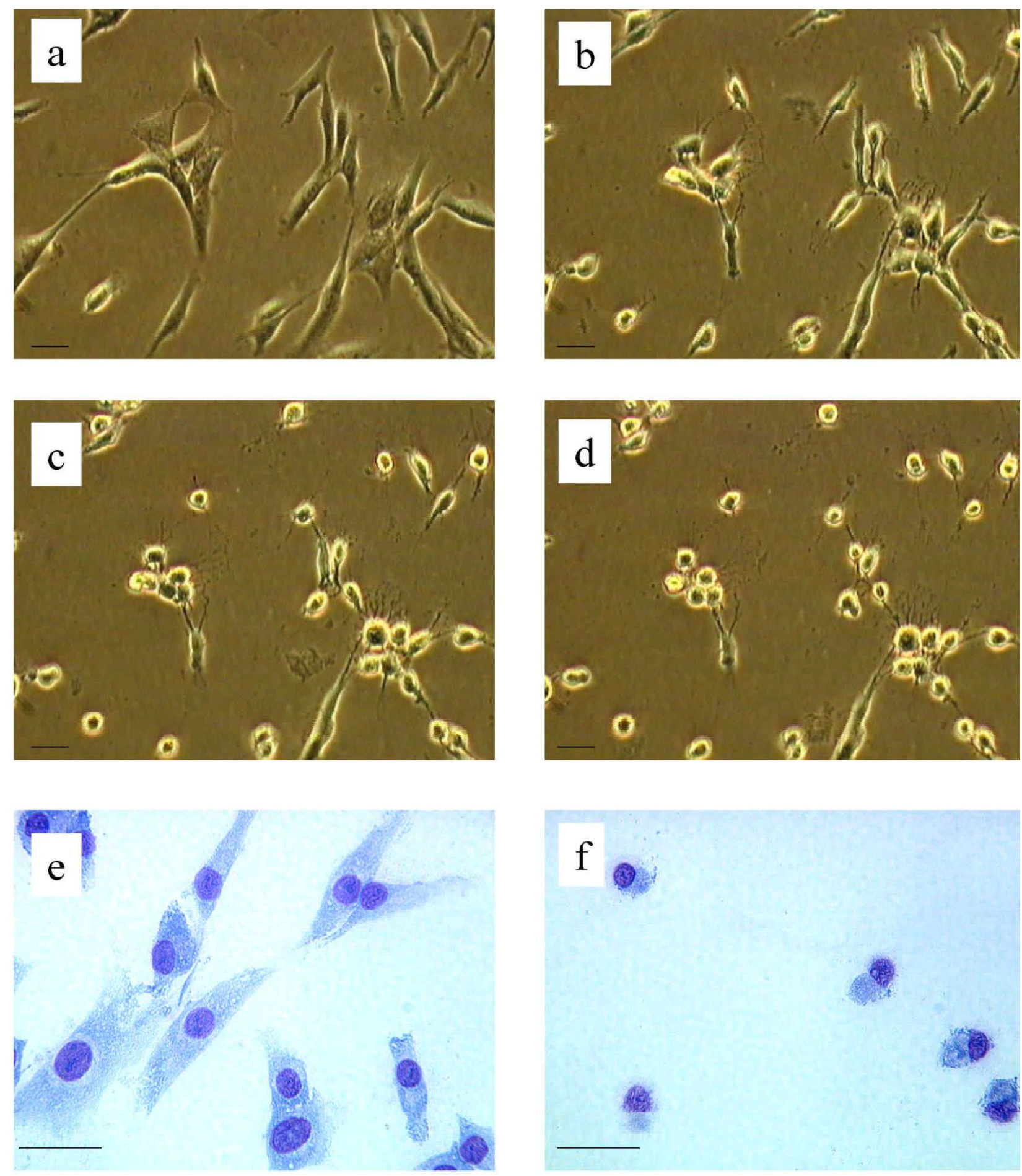

Figure 1. Bis A induces a rounded morphology in monolayered chondrocytes. Representative images of the appearance of chondrocytes prior to bis A treatment (a) and following 20 (b), 40 (c) and 60 (d) minutes of treatment with $100 \mathrm{ng} / \mathrm{ml}$ bis A. Jenner/Giemsa staining of control cells (e) and bis A-treated cells (f) at day 5. Bar $=20 \mu \mathrm{m}$.

remained attached to culture substrates (Fig. 1a-d). This rounded cell shape was maintained in bis A-treated cultures thereafter (Fig. 1e-f). Control chondrocytes proliferated, increasing in cell number from a seeding density of $5 \times 10^{3}$ cells $/ \mathrm{cm}^{2}$ to $27.7 \pm 3.3 \times 10^{3}$ cells $/ \mathrm{cm}^{2}$ by day 5 . However, there was no marked increase in chondrocyte confluency or cell number in bis A-treated cultures. Thus, cultures established at a seeding density of $5 \times 10^{3}$ cells/ $\mathrm{cm}^{2}$ were still only at $7.4 \pm 0.5 \times 10^{3}$ cells $/ \mathrm{cm}^{2}$ by day 5 after the addition of bis A (Fig. 2a). Immunolabelling of cytospins for the proliferation-associated $\mathrm{Ki}-67$ antigen further demonstrated that whilst a large proportion of control cells were proliferative, bis A-treated cells soon exited from cell cycle (Fig. $2 b-d$ ). At day 1, $57 \pm 3 \%$ of 
a
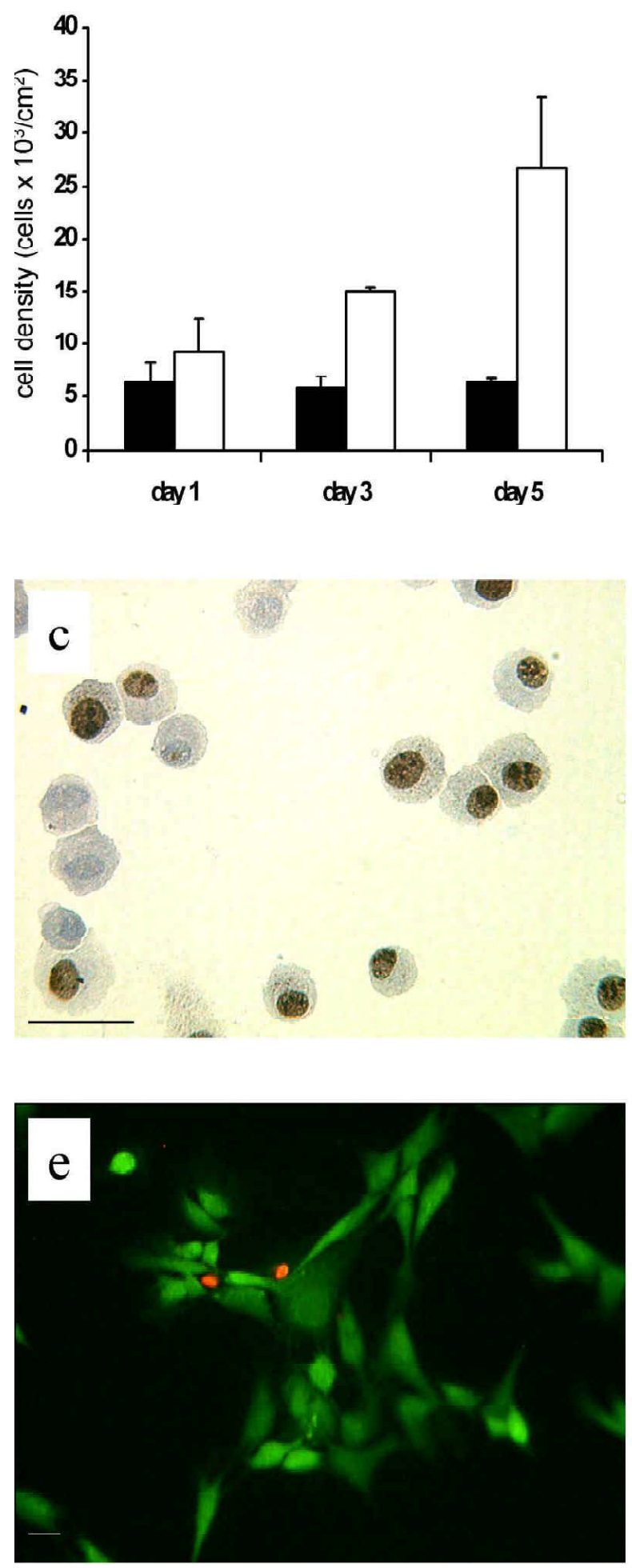

b
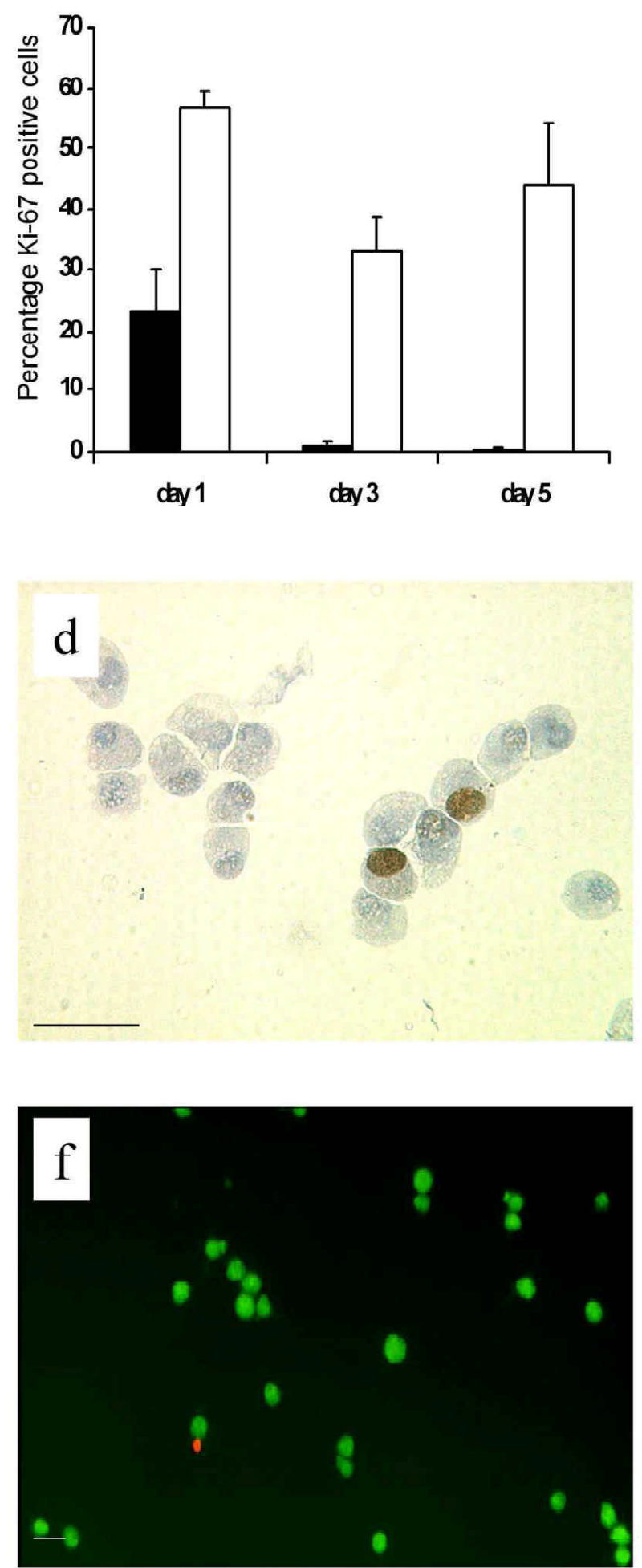

Figure 2. Bis A-induced chondrocyte growth arrest. (a). the density of viable chondrocytes following treatment with carrier alone (control, open bars) or $100 \mathrm{ng} / \mathrm{ml}$ bis A (treated, closed bars) for the times indicated. (b). the proportion of control and treated chondrocytes immunopositive for the Ki-67 antigen at times indicated. Data shown are means \pm standard errors of at least 3 independent experiments. Representative images Ki-67 immunolabelled cytospins of control (c) and bis A-treated chondrocytes (d) at day 1 are also shown. FDA/PI incorporation in chondrocytes demonstrated that the majority of cells in both control (e) and bis A-treated (f) cultures remained viable at day 5 (viable cells appear green, non-viable cells appear red). Bar $=20 \mu \mathrm{m}$ 

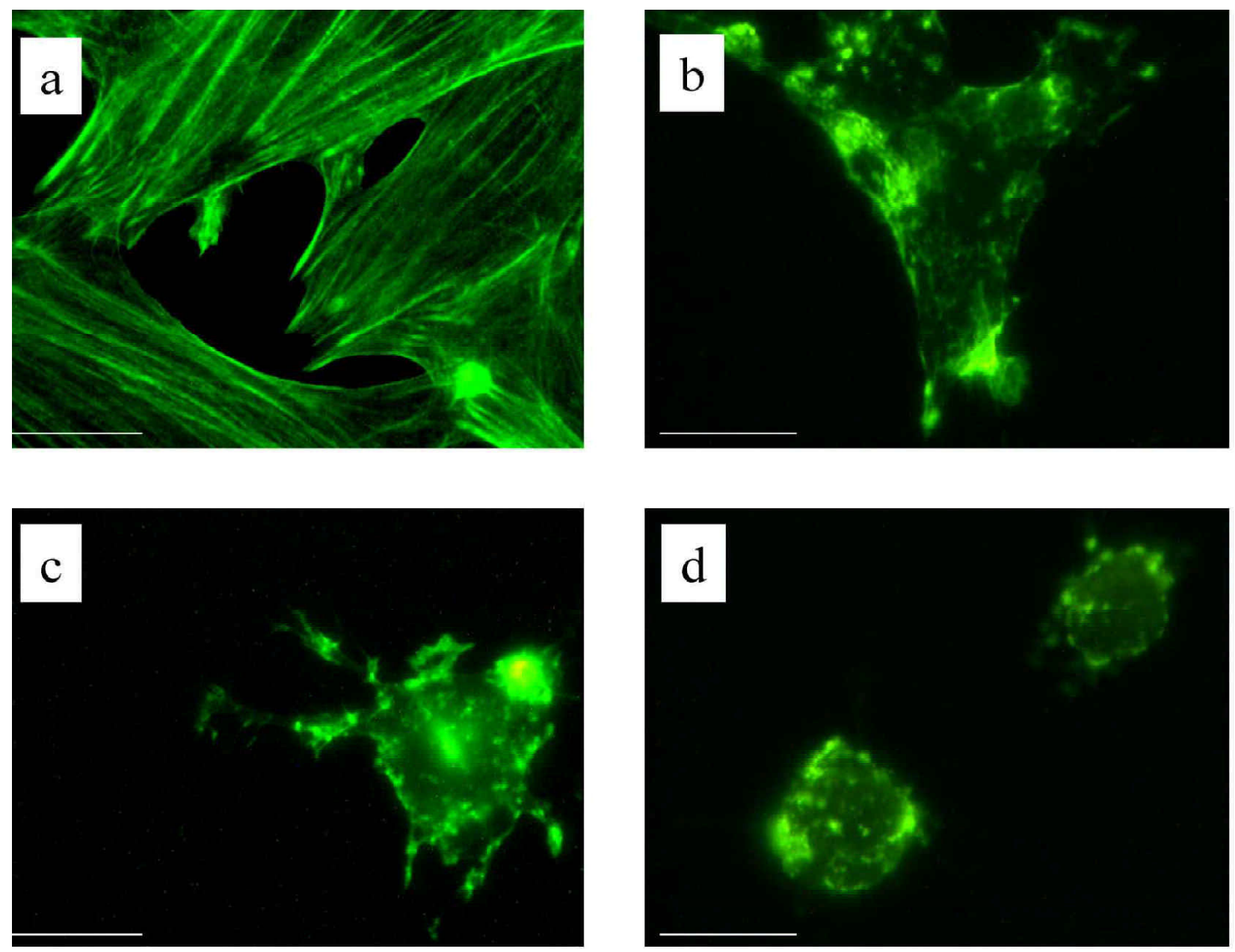

Figure 3. Actin microfilaments are profoundly disrupted by bis A treatment prior to cell rounding. Representative images are shown of the appearance of actin microfilaments within control chondrocytes (a) and in 100ng/ $\mathrm{ml}$ bis A-treated chondrocytes after 10 (b), 20 (c) and 60 (d) minutes. Bar $=20 \mu \mathrm{m}$

control cells were Ki-67-immunopositive, compared with $27 \pm 7 \%$ of bis A-treated cells and by day 3, virtually all bis A-treated cells were immunonegative for the Ki-67 antigen. No cells were detected in culture medium throughout the 5-day time course, indicating that all control and bis A-treated cells remained adherent. Furthermore, cell viability, as determined by trypan blue exclusion and labeling with FDA/PI, remained greater than $95 \%$ in all cultures throughout the 5-day time course (Fig. 2e-f). Thereafter, the cell viability of bis A-treated cultures decreased below $90 \%$. Thus, the initial response of human articular chondrocytes to bis A-treatment was to adopt a rounded morphology and undergo cell growth arrest.

In control cultures, chondrocytes exhibited an F-actin cytoskeleton consisting of numerous, pronounced stress fibres running throughout the cell, parallel to each other or to the cell membrane of extended processes (Fig. 3a). By contrast, after treatment with bis A for only 10 minutes, at a time when the treated chondrocytes were still flattened and spread, these stress fibres were no longer clearly apparent and a more diffuse patch-like pattern of F-actin positivity was observed (Fig. 3b). By 20 minutes, the bis A-treated cells had begun retracting processes and punc- tate F-actin staining was seen in foci throughout the cell (Figure 3c). These foci remained, apparently in association with the cell membrane, in rounded cells following 60 minutes of bis A treatment (Fig. 3d). It appeared, therefore, that the bis A-induced changes in chondrocyte morphology were associated with a prior and extensive disruption of the F-actin cytoskeleton.

Activation of $\mathrm{PKC} \delta$ following bis A treatment has previously been shown to result in rapid translocation of the enzyme from the cytoplasm to the nuclear membrane (Watters et al., 1996; Griffiths et al., 1996). Immunolocalisation of harvested culture slides demonstrated that both control and bis A-treated chondrocytes were immunopositive for PKC $\delta$. In control cells, a diffuse pattern of immunoposivity was observed throughout the cytoplasm. However, increased PKC $\delta$ immunopositivity at the nuclear membrane of treated cells was seen within 60 minutes of the addition of bis A-supplemented medium (Fig. 4a-b). Concurrent treatment of chondrocytes with $100 \mathrm{ng} / \mathrm{ml}$ bis A and concentrations of rottlerin $(5 \mathrm{mM})$ that specifically inhibit $\mathrm{PKC} \delta$, partially blocked the retraction of cell processes and cell rounding, resulting in cells that remained elongated and bipolar after 60 minutes of treatment (Fig. $4 \mathrm{c}-\mathrm{d}$ ), whilst treatment 

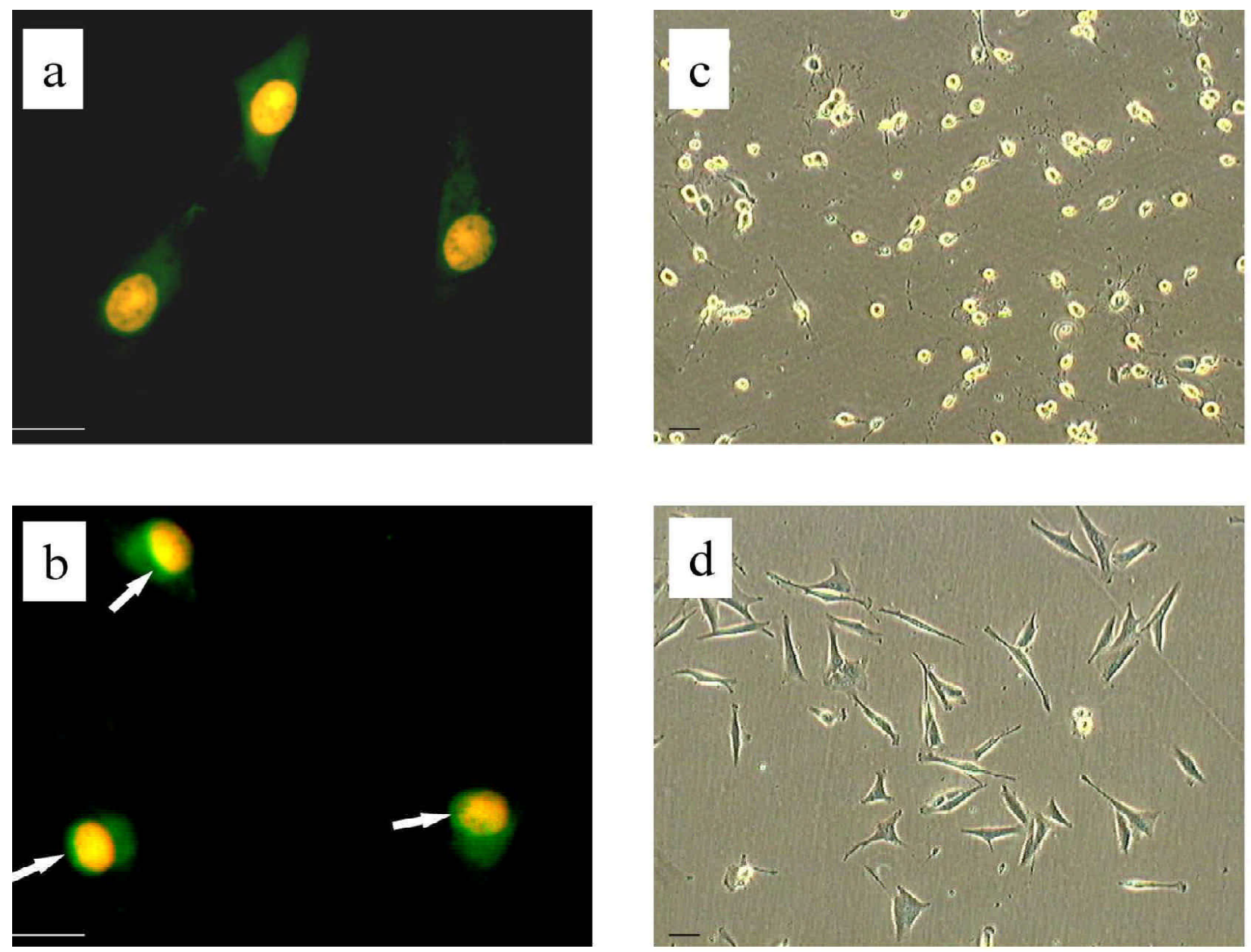

Figure 4. Evidence for $\mathrm{PKC} \delta$ activation in bis A-induced chondrocyte rounding. Representative images of PKC $\delta$ immunostaining in control (a) and bis A-treated (b) chondrocytes at 60 minutes. Increased immunopositivity is evident at the nuclear membrane (arrowed) in bis A-treated cells. Also shown are representative images of the appearance of chondrocytes following 60 minutes of treatment with $100 \mathrm{ng} / \mathrm{ml} \mathrm{bis} \mathrm{A} \mathrm{(c)}$ or following concurrent treatment with $100 \mathrm{ng} / \mathrm{ml}$ bis A and $5 \mathrm{mM}$ rottlerin (d). Bar $=20 \mu \mathrm{m}$

of flattened chondrocytes with rottlerin alone (at $5 \mathrm{mM}$ ) had no effects on morphology.

After 5 days of culture, cytospins of harvested control chondrocytes were either immunonegative or weakly positive for type II collagen. By contrast, type II collagen immunopositivity was observed in day 5 cytospins of all cultures of bis A-treated cells, with a marked increase in pixel intensity, as determined using confocal microscopy of these flattened cell preparations, evident in some of the fluorescein-immunolabelled cells (Fig. 5a-d). The proportions of such strongly immunopositive cells in bis A-treated and control cultures at this time point were $16 \pm 5.6 \%$ and $1.7 \pm 0.4 \%$, respectively. Immunopositivity for type II collagen in day 5 culture slides, revealed with $\mathrm{DAB}$, appeared to be intracellular, distributed diffusely within the cytoplasm, and thus was likely to be for type II procollagen. There was no indication of extracellular type II collagen deposition (Fig. 5e-f). Conversely, immunopositivity for type I collagen was most marked and prevalent in cytospins of control chondrocytes at day 5, compared with cytospins of bis A-treated cells. Simi- larly, the relative pixel intensity of type I collagen immunolabelled cells was seen to decrease in harvested bis A-treated cells in comparison with control cells (Fig. 6a-d). Whilst $76.3 \pm 10.5 \%$ of control cells were strongly immunopositive for type I collagen at day 5, only $13.2 \pm 3.1 \%$ of bis A-treated cells were similarly immunopositive. Type I collagen immunopositivity of day 5 culture slides also appeared to be intracellular, distributed in a punctate pattern throughout the cytoplasm, and thus was most likely to be for type I procollagen (Fig. $6 e-f)$. There were no apparent differences in any of the reported behaviour of the cultured chondrocytes in response to bis A treatment that related to biopsy location, donor age, sex or pathology.

\section{Discussion}

To further our understanding of regulatory mechanisms that affect the differentiation status of human articular chondrocytes, we have examined the effects of treating cultured cells with a specific activator of $\mathrm{PKC} \delta$, bistratene 

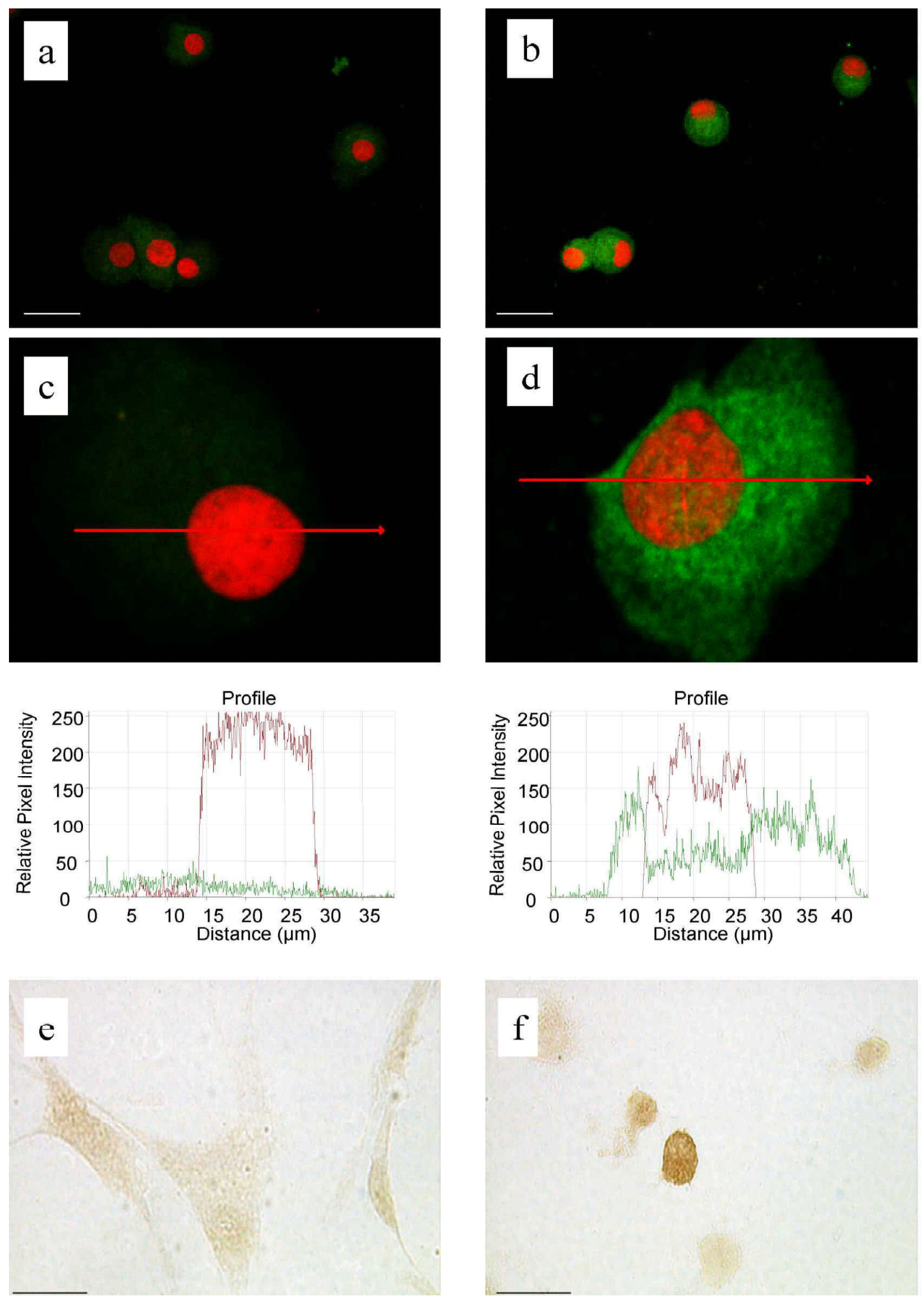

Figure 5. Type II collagen immunopositivity increases following bis A treatment. Control (a and c) and 100ng/ $\mathrm{ml}$ bis A-treated ( $\mathrm{b}$ and $\mathrm{d}$ ) chondrocytes following type II collagen immunolocalisation of day 5 cytospins: the relative pixel intensity through the transecting lines of representative fluorescein-immunolabelled cells are shown in the bottom panels of $\mathrm{c}$ and $\mathrm{d}$, where green is fluorescein-label and red is PI. The intracellular immunolocalisation apparent in day 5 control (e) and bis A-treated (f) culture slides suggests that type II procollagen was detected. Bar $=30 \mu \mathrm{m}$ 

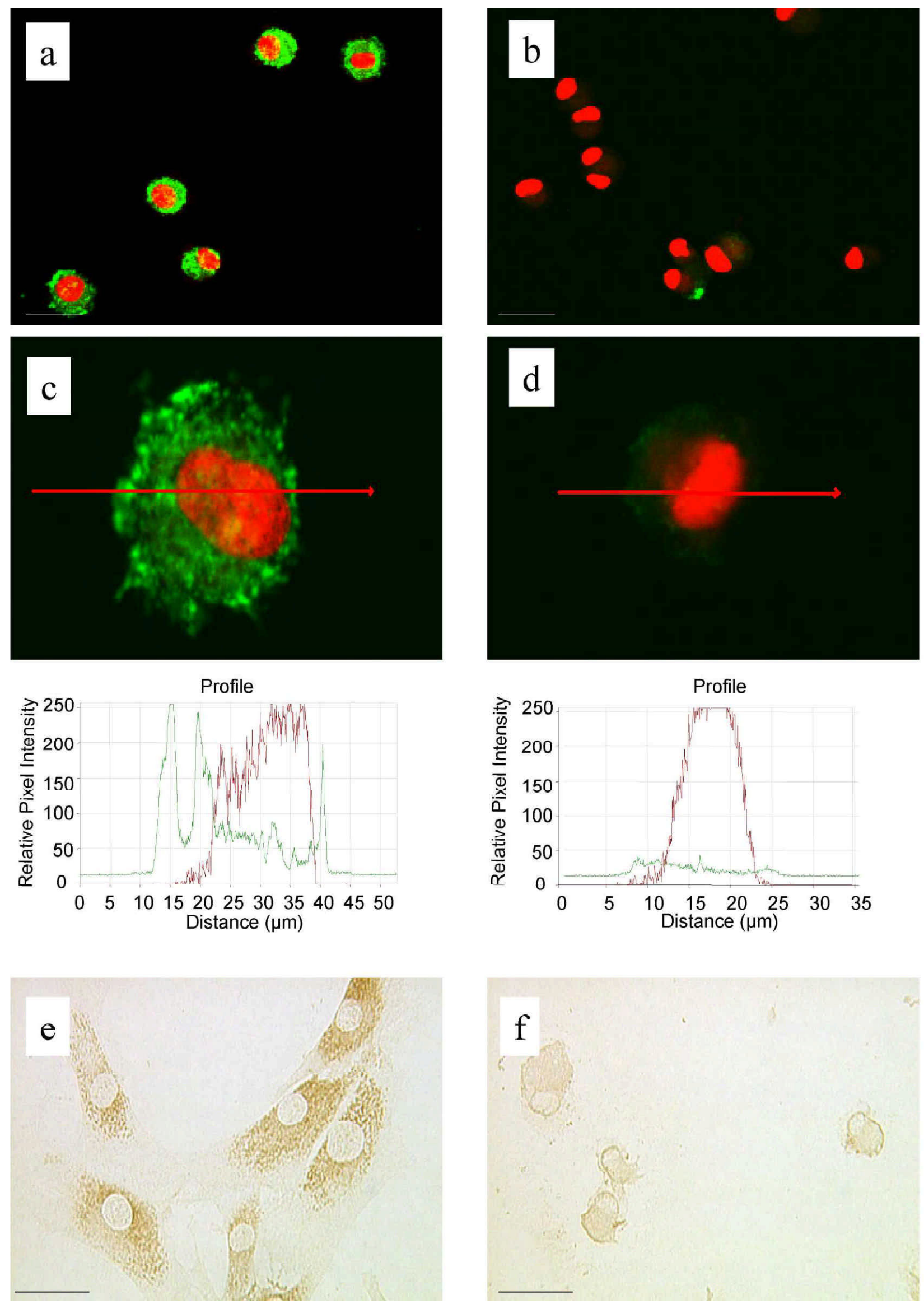

Figure 6. Type I collagen immunopositivity decreases following bis A treatment. Control (a and c) and 100ng/ $\mathrm{ml}$ bis A-treated ( $\mathrm{b}$ and $\mathrm{d}$ ) chondrocytes following type I collagen immunolocalisation of day 5 cytospins: the relative pixel intensity through the transecting lines of representative fluorescein-immunolabelled cells are shown in the bottom panels of $\mathrm{c}$ and $\mathrm{d}$, where green is fluorescein-label and red is PI. The intracellular immunolocalisation apparent in day 5 control (e) and bis A-treated (f) culture slides suggests that type I procollagen was detected. Bar $=30 \mu \mathrm{m}$ 
A (bis A). The responses of these cells in monolayer culture to such treatment were very similar to those reported for primary human fibroblasts (Watters et al., 1996), with a loss of actin stress fibres and cell rounding. In contrast to this previous study, however, human chondrocytes remained firmly adherent when rounded. The bis A-induced morphological changes were associated with chondrocyte growth arrest and an increase in immunopositivity for the differentiated chondrocyte marker, type II collagen. Conversely, type I collagen immunopositivity was markedly less intense (or absent) in bis A-treated cells in comparison to control cells. Immunopositivity for both of these markers appeared to be intracellular and therefore was most likely to represent antibody binding to the procollagen forms. In addition, we have shown that bis A-treatment was associated with a translocation of PKC $\delta$ to the nuclear membrane. Identical translocations of the activated enzyme have previously been shown in human fibroblasts and leukemic cells following bis A treatment (Watters et al., 1996; Griffiths et al., 1996). Furthermore, the morphological effects of bis A on chondrocytes were abrogated by concurrent treatment with rottlerin, at doses that specifically inhibit the delta isoform of the PKC family (Gschwendt et al., 1994). Taken together, these observations suggest that the morphological effects of bis A on cultured chondrocytes were associated with $\mathrm{PKC} \delta$ activation.

To our knowledge, this study is the first to identify $\mathrm{PKC} \delta$ as having a regulatory role in determining chondrocyte shape; however, further studies are required to determine the relationship between PKC $\delta$ activation and the subsequent chondrocyte growth arrest and alterations in collagen expression. Not least, PKC $\delta$ is an important regulator of apoptosis in other cell types, notably neutrophils (Pongracz et al., 1999; Webb et al., 2000; Cross et al., 2000). In the present study, chondrocyte viability remained greater than $95 \%$ thoughout the experimental time course, but subsequently decreased in bis A-treated cultures. The growth arrest and alterations in collagen expression of bis A-treated chondrocytes may therefore represent part of a "default" response of these cells that is associated with inductions of cell death, rather than being part of any physiological, maturation pathway. Conversely, as $\mathrm{PKC} \delta$ activation has also been associated with increased cell maturation in a number of systems (Denning et al., 2000; Watters and Parsons, 1999; Watters et al., 1998), the decreased viability of chondrocytes following bis A-treatment may occur independently or even as a consequence of this maturation. To some extent, the findings are thereby limited by the use of pharmacological agents, where pleiotropic effects may operate. Nonetheless, this study implicates PKC $\delta$ activation in the regulation of chondrocyte gene expression.

In mesenchymal limb bud cultures, activation of different PKC isoforms, notably the alpha isoenzyme $(\mathrm{PKC} \alpha)$, is both associated with and required for chondrocyte maturation (Yang et al., 1998; Choi et al., 1995). Treatments of developing mesenchyme with PKC inhibitors or with doses of phorbol ester that down-regulate
PKC $\alpha$ inhibit chondrogenesis, and these effects are mediated through increased Erk-1 activity and are associated with increased and prolonged expression of alpha5beta1 integrins (Chang et al., 1998). Chondrogenesis of cultured chick limb mesenchymal cells, delineated by collagen II upregulation and cell rounding, has also previously been demonstrated following treatments with the actin microfilament disrupting agent, dihydrocytochalasin B (Zanetti and Solursh, 1984). Interestingly, it has recently been shown that such treatment results in PKC $\alpha$ upregulation and activation, Erk-1 inhibition and then type II collagen expression (Lim et al., 2000). An intriguing report has also recently shown that ectopic overexpression of PKC $\alpha$ in Baf3 cells results in increased endogenous synthesis of PKC $\delta$, but has no effect on expression of the epsilon, eta or mu isoforms (Romanova et al., 1998). This study thereby demonstrates specific cross-talk between the alpha and delta isoforms of PKC that may regulate cell shape. The bis A-induced alterations in chondrocyte behaviour reported here may, therefore, provide a new model system to study an as yet unresolved pathway, potentially involving cytoskeletal and signalling components, that regulates chondrocyte differentiation in vitro.

\section{Acknowledgements}

We are grateful to Dr Dianne Watters for the kind gift of bistratene A. This work was undertaken in the Robert Jones and Agnes Hunt Orthopaedic and District Hospital NHS Trust who received a proportion of its funding from the NHS executive; the views expressed in this publication are those of the authors.

\section{References}

Barry ST, Critchley DR (1994) The RhoA-dependent assembly of focal adhesions in Swiss 3T3 cells is associated with increased tyrosine phosphorylation and the recruitment of both pp125FAK and protein kinase C-delta to focal adhesions. J Cell Sci 107: 2033-2045.

Benya PD, Shaffer JD (1982) Dedifferentiated chondrocytes reexpress the differentiated collagen phenotype when cultured in agarose gels. Cell 30: 215-224.

Benya PD, Padilla SR, Nimni ME (1978) Independent regulation of collagen types by chondrocytes during the loss of differentiated function in culture. Cell 15: 1313-1321.

Benya PD, Brown PD, Padilla S (1988) Microfilament modification by dihydrocytochalasin $\mathrm{B}$ causes retinoic acid-modulated chondrocytes to reexpress the differentiated collagen phenotype without a change in shape. J Cell Biol 106: 161-170.

Brown PD, Benya PD (1988) Alterations in chondrocyte cytoskeletal architecture during phenotypic modulation by retinoic acid and dihydrocytochalasin B-induced reexpression. J Cell Biol 106: 171-179.

Chang SH, Oh CD, Yang MS, Kang SS, Lee YS, Sonn JK, Chun JS (1998) Protein kinase C regulates chondrogenesis of mesenchymes via mitogen-activated protein 
kinase signaling. J Biol Chem 273: 19213-19219.

Choi B, Chun JS, Lee YS, Sonn JK, Kang SS (1995)

Expression of protein kinase $\mathrm{C}$ isozymes that are required for chondrogenesis of chick limb bud mesenchymal cells. Biochem Biophys Res Commun 216: 1034-1040.

Cross T, Griffiths G, Deacon E, Sallis R, Gough M, Watters D, Lord JM (2000) PKC-delta is an apoptotic lamin kinase. Oncogene 19: 2331-2337.

Denning MF, Dlugosz AA, Cheng C, Dempsey PJ, Coffey RJ, Threadgill DW, Magnuson T, Yuspa SH (2000) Cross-talk between epidermal growth factor receptor and protein linase $\mathrm{C}$ during calcium-induced differentiation of keratinocytes. Exp Dermatol 9:192-199.

Freed LE, Vunjak-Novakovic G, Biron RJ, Eagles DB, Lesnoy DC, Barlow SK, Langer R (1994) Biodegradable polymer scaffolds for tissue engineering. Biotechnology (N Y) 12: 689-693.

Griffiths G, Garrone B, Deacon E, Owen P, Pongracz J, Mead G, Bradwell A, Watters D, Lord J (1996) The polyether bistratene A activates protein kinase $\mathrm{C}$-delta and induces growth arrest in HL60 cells. Biochem Biophys Res. Commun 222: 802-808.

Gschwendt M, Muller HJ, Kielbassa K, Zang R, Kittstein W, Rincke G, Marks F (1994) Rottlerin, a novel protein kinase inhibitor. Biochem Biophys Res Commun 199: 93-8.

Jones KH, Senft JA (1985) An improved method to determine cell viability by simultaneous staining with fluorescein diacetate-propidium iodide. J Histochem Cytochem 33: 77-79.

Lim YB, Kang SS, Park TK, Lee YS, Chun JS, Sonn JK (2000) Disruption of actin cytoskeleton induces chondrogenesis of mesenchymal cells by activating protein kinase C-alpha signaling. Biochem Biophys Res Commun 273: 609-613.

Mallein-Gerin F, Garrone R, van der Rest M (1991) Proteoglycan and collagen synthesis are correlated with actin organization in dedifferentiating chondrocytes. Eur J Cell Biol 56: 364-373.

Mischak H, Goodnight JA, Kolch W, Martiny-Brown G, Schaechtle C, Kazanietz MG, Blumberg PM, Pierce JH, Mushinski JF (1993) Overexpression of protein kinase C-delta and -epsilon in NIH 3T3 cells induces opposite effects on growth, morphology, anchorage dependence, and tumorigenicity. J Biol Chem 268: 6090-6096.

Pongracz J, Webb P, Wang K, Deacon E, Lunn OJ,
Lord JM (1999) Spontaneous neutrophil apoptosis involves caspase 3-mediated activation of protein kinase Cdelta. J Biol Chem 274: 37329-37334.

Richardson JB, Caterson B, Evans EH, Ashton BA, Roberts S (1999) Repair of human articular cartilage after implantation of autologous chondrocytes. J Bone Joint Surg. Br 81: 1064-1068.

Romanova LY, Alexandrov IA, Nordan RP, Blagosklonny MV, Mushinski JF (1998) Cross-talk between protein kinase $\mathrm{C}$-alpha (PKC-alpha) and -delta (PKC-delta): PKC-alpha elevates the PKC-delta protein level, altering its mRNA transcription and degradation. Biochemistry 37: 5558-5565.

Romanova LY, Alexandrov IA, Blagosklonny MV, Nordan RP, Garfield S, Acs P, Nguyen P, Trepel J, Blumberg PM, Mushinski JF (1999) Regulation of actin cytoskeleton in lymphocytes: PKC-delta disrupts IL-3induced membrane ruffles downstream of Rac1. J Cell Physiol 179: 157-169.

von der Mark K, Gauss V, von der Mark H, Müller P (1977) Relationship between cell shape and type of collagen synthesised as chondrocytes lose their cartilage phenotype in culture. Nature 267: 531-532.

Watters D, Parson PG (1999) Critical targets of protein kinase $\mathrm{C}$ in differentiation of tumour cells. Biochem Pharmacol 58: 383-388.

Watters D, Garrone B, Gobert G, Williams S, Gardiner R, Lavin M (1996). Bistratene A causes phosphorylation of talin and redistribution of actin microfilaments in fibroblasts: possible role for PKC-delta. Exp Cell Res 229, 327-335.

Watters D, Garrone B, Coomer J, Johnson WE, Brown G, Parsons P (1998) Stimulation of melanogenesis in a human melanoma cell line by bistratene A. Biochem. Pharmacol. 55: 1691-1699.

Webb PR, Wang KQ, Scheel-Toellner D, Pongracz J, Salmon M, Lord JM (2000) Regulation of neutrophil apoptosis: a role for protein kinase $\mathrm{C}$ and phosphatidylinositol-3-kinase. Apoptosis 5: 451-458.

Yang MS, Chang SH, Sonn JK, Lee YS, Kang SS, Park TK, Chun JS (1998) Regulation of chondrogenic differentiation of mesenchymes by protein kinase $\mathrm{C}$ alpha. Mol Cells 8: 266-271.

Zanetti NC, Solursh M (1984) Induction of chondrogenesis in limb mesenchymal cultures by disruption of the actin cytoskeleton. J Cell Biol 99: 115-123. 